\title{
IEA and lighting retrofit in buildings
}

\begin{abstract}
The existing performed building stock in individual countries is very large and a lot of buildings require a retrofit of lighting systems to be more energy efficient, comfortable for users and adaptable to the visual work requirements. Activities orientated to looking for a system of requirements, criteria and parameters for retrofit of lighting systems in commercial buildings are main interest of the IEA SHC Task 50 since 2013. Because interiors are illuminated by daylight and artificial light, the research of the IEA SHC Task 50 couples effects from both as the best. The result of the collective work should be also an application "Lighting Retrofit Adviser", a tool for illuminating engineers. This contribution gives latest information about the activities of the IEA SHC Task 50
\end{abstract}

Keywords: Lighting retrofit, daylighting, lighting evaluation criteria, Lighting Retrofit Adviser.

\section{Introduction}

The energy consumption during building performance covers human needs for heating, air-condition, hot water production, illuminating and depends on the thermal and optical properties of own and surrounding building constructions and local climatic conditions. All built in technologies significantly influence quality of thermal and visual indoor environment. There are a lot of buildings constructed in the last century which are illuminated by conventional incandescent lamps or fluorescent lamps. Nowadays, new more lighting and energy efficient technologies for illumination of interiors are available in the market. About $75 \%$ of the lighting systems are in these buildings obsolete (older than 25 years) and require removing, renovation or retrofit, [1, 2].

Since 1977 the programme SHC - Solar Heating \& Cooling is opened in IEA - International Energy Agency for international R\&D cooperation, standardisation and acceleration of the technology development in the practice. Since 2013 the project IEA SHC Task 50 "Advanced Lighting Solutions for Retrofitting Buildings" is solved by numerous specialists from research, academic, design and industry area.

\section{Description of IEA SHC Task 50 activities}

The project of IEA SHC Task 50 is focus on the improving the lighting refurbishment process in nonresidential buildings to save energy and at the same time to improve indoor lighting quality. The basic information about IEA SHC Task 50 activities can be found on the WWW site http://task50.iea-shc.org, [3]. The retrofit of electric lighting and daylighting solutions in the non-domestic sector using cost effective and best-practice approaches are main objectives of this project. Solutions should be addressed to lighting retrofit market, should initiate revision and enhancement of local and national regulations and certifications and should increase understanding of lighting retrofit processes due to adequate information. The electronic interactive source book as a design advice, decision and design tool is main goal of the project.

Research activities are carried out in the framework of the four subtasks and one joint working group:

- subtask A: Market and Policies,

- subtask B: Daylighting and Electric Lighting Solutions,

- subtask C: Methods and Tools,

- subtask D: Case Studies,

- Joint Working Group: "Lighting Retrofit Adviser".
Project is operated by Jan de Boer from Fraunhofer Institute of Building Physics, Stuttgart, Germany. Leaders of subtasks are listed in Table 1 while in the Table 2 is sumarised number of participants selected by nationality.

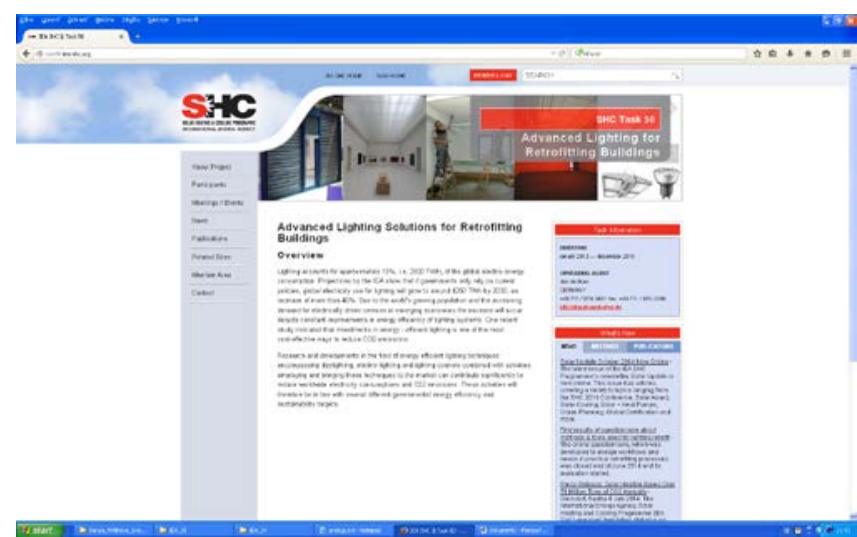

Fig. 1. The main WWW side of the IEA SHC Task 50 (http:// //task50.iea-shc.org)

Table 1. List of subtask leaders

\begin{tabular}{|c|l|}
\hline Subtask & \multicolumn{1}{|c|}{ Leader } \\
\hline \multirow{3}{*}{ A } & Professor Marc Fontoynont \\
\cline { 2 - 3 } & $\begin{array}{l}\text { Danish Building Research Institute Copenhagen, } \\
\text { Denmark }\end{array}$ \\
\hline \multirow{2}{*}{ B } & Dr. Martine Knoop \\
\cline { 2 - 3 } & Technische Universität Berlin, Germany \\
\hline \multirow{4}{*}{ C } & Dr. Jérôme Kaempf \\
\cline { 2 - 2 } & $\begin{array}{l}\text { Ecole Polytechnique Fédérale de Lausanne, } \\
\text { Lausanne, Switzerland }\end{array}$ \\
\cline { 2 - 2 } & Dr. Bernard Paule \\
\cline { 2 - 2 } & Estia SA, Lausanne, Switzerland \\
\hline \multirow{2}{*}{ D } & Associate Professor Marie-Claude Dubois \\
\cline { 2 - 2 } & Lund University, Lund, Sweden \\
\hline
\end{tabular}

Table 2. Number of participants

\begin{tabular}{|l|l|l|l|l|l|}
\hline Austria & 2 & Germany & & Slovakia & 2 \\
\hline Belgium & 2 & Italy & 9 & Sweden & 3 \\
\hline China & 1 & Japan & 2 & Switzerland & 4 \\
\hline Denmark & 3 & Netherlands & 1 & & \\
\hline Finland & 1 & Norway & 2 & & \\
\hline
\end{tabular}

In the Subtask A there are identified various possible approaches of retrofitting daylighting systems and lighting installations in buildings in the point of view added benefits for investors, building owners and occupants. The Subtask $B$ is concentrated on the assessment of existing and new technical solutions in the field of façade and daylighting technology, daylighting and artificial lighting and lighting 
controls. Under the Subtask C simple computer design tools and methods are analysed to improve the understanding of retrofit processes. This covers calculation methods for optimization of lighting solutions, energy auditing and inspection procedures. Numerous analyses of application various new technologies in lighting systems in various building types are provided and evaluated within Subtask D. Role of the Joint Working Group is to develop algorithm and to write code for application "Lighting Retrofit Adviser".

\section{Daylighting and artificial lighting retrofit aspects}

New materials, building constructions, lighting and control systems offer architects better utilisation of skylight and sunlight. If existing buildings are renovated, often also thermal properties of envelopes and windows are redesigned. In this process is crucial to consider as much as possible aspects influencing quality of visual environment and energy consumption of lighting system during its operation. In IEA SHC Task 50 were identified retrofit aspects and simple matrix of retrofit solutions was discussed, Table 3 . On the left side in this table are listed constructions and devices associated with lighting retrofit while on the right side are mentioned possible activity areas.

Table 3. Matrix of retrofit solutions

Table 3. Matrix of retrofit solutions
\begin{tabular}{|l|l|l|l|}
\hline $\begin{array}{l}\text { Façade and daylighting } \\
\text { technology }\end{array}$ & & $\begin{array}{l}\text { Upgrade of existing } \\
\text { situation }\end{array}$ \\
\hline $\begin{array}{l}\text { Blinds and shading } \\
\text { technology }\end{array}$ & & $\begin{array}{l}\text { Use new components } \\
\text { in existing situation }\end{array}$ \\
\hline Electric lighting solutions & & & \\
\hline Electric lighting controls & & & Redesign \\
\hline Changes to the interiors & & & \\
\hline
\end{tabular}

To fulfil good practice of lighting retrofit the design and evaluation criteria were proposed in the areas of indoor environment quality, energy efficiency, electric lighting performance and costs as follows:

- Quality measures

reduce energy consumption,

increase the light quality, and

reduce the operational costs.

- Energy efficiency

personal control,

daylight harvesting,

occupancy sensing,

tuning.

- Thermal considerations

- Lighting quality

colour rendering index,

colour temperature,

directionality,

glare protection,

light distribution,

view out,

privacy at night.

- Maintenance

Lamp life,

Lumen depreciation over lifetime,

re-commissioning.

- Costs

initial costs,

operational costs.

\section{Daylight measures and daylight technology}

There are several approaches to the evaluation of the daylight utilisation on energy consumption in the point of view of interior illumination. Set of aspects: energy efficiency, daylight usage, lighting quality and maintenance were proposed and analysed. Over 30 measures like using direct sunlight, glare protection, visual transmittance, view out, colour distortion, personal control possibilities, thermal consideration, visible to thermal ratio, classification of labour / time, initial costs, running costs, maintenance, visual comfort, primarily focus on the lighting retrofit to:

- reduce energy consumption,

- increase the light quality, and

- reduce the operational costs.

It had occurred that scaling of energy efficiency and lighting quality of technologies to be applied are good indicators for energy strategy scheme. Daylight technologies due to combination of both these aspects were evaluated to determine suitability and effectiveness for lighting retrofit. Validation of measures is either in the scale of $0-1$ or in percentage. Because quality criteria $Q C$ have various impact on the lighting retrofit the weighting factor $W$ $s$ of values $0.05-1$ were used. Then information level of the technology is calculated as:

$$
\sum W \times Q C=\left[\begin{array}{l}
- \text { low } \\
- \text { middle } \\
- \text { very }
\end{array}\right.
$$

Author analysed impact of louvers, exterior shading devices, on the sunlight direct control.

\section{Lighting Retrofit Adviser (LRA)}

A simple software "Lighting Retrofit Adviser" as source e-book for mobile application (Android, iOS, Windows Phone), HTML 5 is currently developing. The first visualisation of its main window is shown in Figure 2.

\section{Lighting Retrofit Adviser}

design inspirations, design advice, decision and designtools for relighting

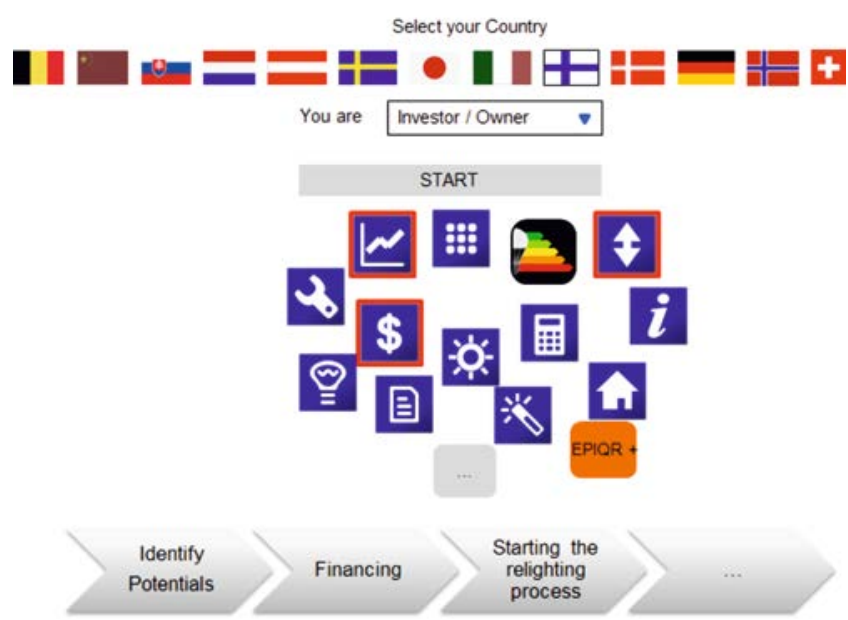

Fig. 2. Main window of the Lighting Retrofit Adviser (first visualisation)

After enter in the system, user can be navigated from Main Window to Technology Consultant; Portfolio Analysis; 
Collection of Tools; Benchmarking; Case Studies; Markets and Policies as well as Catalogue of Products. All of these sides will offer users a lot of information applicable in the decision and design retrofit process.

\section{Conclusions}

All IEA SHC Task 50 activities will finish in December 2015. It is assumption that in the early of 2016 the application "Lighting Retrofit Adviser" will be in full operation and available for practical use.

Results will be published in the interactive source book. Architects and illuminating engineers expect information not only about the best daylight solutions but they also appreciate also information about advantages and disadvantages of the applicable technologies for the lighting retrofit. Therefore the technology fitches of louvers categorised after material base will be part of the book source.

Acknowledgments: This paper was elaborated thanks project MVTS IEA SHC TASK 50 and inputs to the catalogue criteria were supported by project VEGA $2 / 0117 / 14$

\section{REFERENCES}

[1] Mahlia, T.M.I., Said, M.F.M., Masjuki, H.H., Tamjis, M.R., Costbenefit analysis and emission reduction of lighting retrofits in residential sector, Energy and Buildings, 37 (2005), 573-578

[2] Lee. A.H.W. Verification of electrical energy savings for lighting retrofits using short- and long-term monitoring, Energy Conversion \& Management, 41 (2000), 1999-2008

[3] IEA SHC Task 50, website: http:// //task50.iea-shc.org

\footnotetext{
Authors: Associate Professor Stanislav Darula, PhD., Institute of Construction and Architecture, Slovak Academy of Sciences, Dubravska cesta 9, SK-845 03 Bratislava 45, Slovakia, e-mail: usarsdar@savba.sk

Dipl. Ing. Marta Malíková, Institute of Construction and Architecture, Slovak Academy of Sciences, Dubravska cesta 9, SK-
} 84503 Bratislava 45, Slovakia, e-mail: malikova.marta@savba.sk 